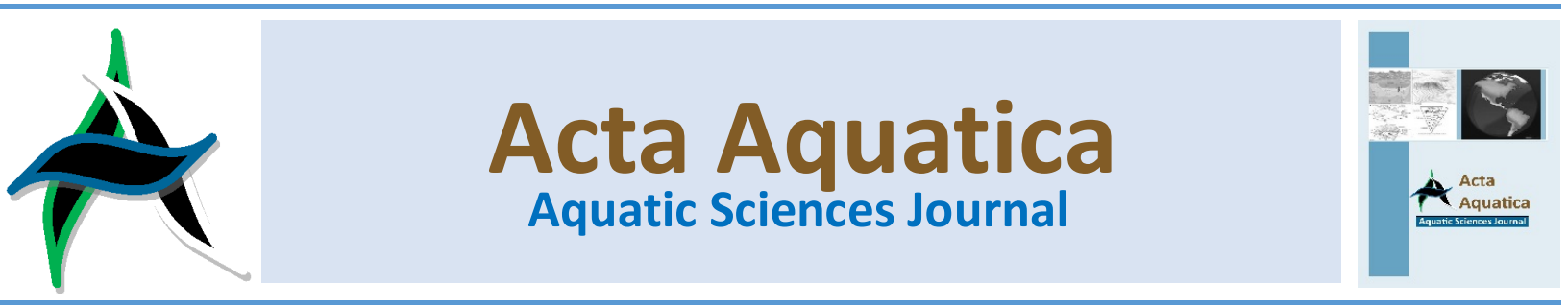

\title{
Identifikasi kawasan penangkapan induk udang windu (Penaeus monodon) pada perairan pesisir Kabupaten Aceh Jaya
}

\section{Identification of the catchment areas of tiger prawn (Penaeus monodon) broodstock in the coastal water of Aceh Jaya region}

\author{
Munawar Khalil a, *, Zulfikar a dan Saifullah ${ }^{\text {b }}$ \\ a Program Studi Budidaya Perairan, Fakultas Pertanian. Universitas Malikussaleh. Aceh, Indonesia \\ ${ }^{b}$ Dinas Kelautan dan Perikanan Kota Sabang. Aceh, Indonesia
}

\begin{abstract}
Abstrak
Tujuan penelitian ini adalah untuk menetapkan kawasan penangkapan induk udang windu (Penaeus monodon) dan kondisi lingkungan perairannya ditinjau dari aspek fisika kimia perairan pada kawasan perairan kabupaten Aceh Jaya. Penelitian ini menggunakan pendekatan survey dan teknologi system informasi geografis. Kawasan penangkapan induk udang di Kabupaten Aceh Jaya pada umumnya terdapat pada titik ordinat: (1) H $95^{\circ} 34^{\prime}$ bujur timur dan $04^{\circ} 38^{\prime}$ lintang utara, (2) H $95^{\circ} 33^{\prime}$ bujur timur dan $04^{\circ} 39^{\prime}$ lintang utara, (3) H $95^{\circ} 34^{\prime}$ bujur timur dan $04^{\circ} 40^{\prime}$ lintang utara, (4) H $95^{\circ} 34^{\prime}$ bujur timur dan $04^{\circ} 33^{\prime}$ lintang utara. Parameter fisika kimia perairan yang diukur pada kawasan penangkapan induk udang menunjukkan kondisi yang sangat sesuai bagi sistem kehidupan udang.
\end{abstract}

Kata kunci: Titik ordinat; Induk udang; Sistem informasi geofgrafis; Paremeter fisika kimia perairan

\begin{abstract}
The aims of this study was to establish the broodstock catchment areas of tiger prawn (Penaeus monodon) and the condition of the waters which was surrounding their habitat in terms of environmental aspects of physical chemical water parameter in the coastal waters of Aceh Jaya region. This study used survey approach and geographic information system technology as methodelogy. The catching areas of broodstock in Aceh Jaya region commonly found on the ordinate point: (1) $\mathrm{H} 95^{\circ} 34^{\prime}$ east longitude and $04^{\circ} 38^{\prime}$ north, (2) $\mathrm{H} 95^{\circ} 33^{\prime}$ east and $04^{\circ} 39^{\prime}$ north,

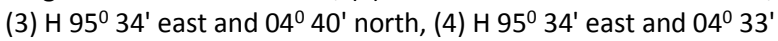
north. Physical and chemical parameters of water measured at catchment areas showed that the water parameters in the prawn habitat were very suitable for supporting of tiger prawn living.
\end{abstract}

Keywords: Ordinat spots; Prawn broodstock; Geographic information system; Physical and chemical water parameters

\section{Pendahuluan \\ 1.1. Latar belakang}

Indonesia merupakan negara kepulauan terbesar di dunia dengan sumberdaya perikanannya yang potensial dikembangkan. Satu komoditi perikanan yang penting adalah udang. Udang bernilai niaga tinggi, telah banyak menyumbang devisa bagi negara, dan sebagian besar masa hidupnya berada di dasar perairan. Di perairan Indonesia lebih banyak dijumpai jenis-jenis udang dari famili Penaeidae, terutama genus Penaeus, diantaranya adalah Penaeus merguiensis. Penyebaran udang di Indonesia hampir meliputi seluruh perairan Indonesia, mulai dari perairan barat Indonesia hingga ke perairan di sebelah timur (Adnyana, 1992). Hal ini ditunjukkan dengan luasnya penyebaran

* Korespondensi: Prodi Budidaya Perairan, Fakultas Pertanian, Universitas Malikussaleh. Kampus utama Reuleut,

Kabupaten Aceh Utara, Aceh, Indonesia.

Tel: +62-645-41373 Fax: +62-645-59089.

E-mail: khalil.id@live.com alat penangkap udang yang sering digunakan oleh nelayan Indonesia.

Keanekaragaman spesies crustacea diperkirakan mencapai lebih dari 1.502 spesies. Dari jumlah tersebut terdapat 83 jenis udang yang termasuk suku Penaedae yang merupakan jenis udang konsumsi dan dalam perdagangan dikategorikan sebagai spesies ekonomi penting. Diperkirakan ada 11 spesies udang laut (Penaeidae), 7 Spesies udang karang (Dahuri et al., 2001). Jenis-jenis udang laut dari marga Penaeus dan Metapenaeus memiliki dua fase siklus hidup yaitu fase di tengah laut jeluk pada saat dewasa dan memijah serta fase di perairan pantai pada saat juvenile dan juwana. Pada fase juvenil, udangudang ini sangat bergantung pada ekosistem hutan mangrove karena pada fase ini udang-udang ini mencari makan berbagai jasad renik (mikro algae) dan detritus yang jumlahnya berlimpah di kawasan hutan mangrove. Oleh karena itu, kegiatan penangkapan udang pada umumnya dilakukan pada kawasankawasan pesisir yang ditumbuhi hutan mangrove.

Tingginya potensi sumberdaya perairan Indonesia terutama dari jenis udang-udangan merupakan hal 
menguntungkan untuk mendukung pengembangan suatu model pengelolaan melalui teknik pembudidayaan mengingat sumberdaya tersebut semakin lama semakin menunjukkan gejala penurunan. Hal awal yang harus dilakukan bagi pengembangan sektor budidaya adalah penyediaan jenis-jenis induk udang yang unggul baik melalui pengambilan langsung dari alam maupun hasil pengembangan budidaya.

Berkaitan dengan biota yang dibudidayakan, ketersediaannya dalam jumlah yang cukup merupakan hal pokok yang harus terpenuhi untuk menilai tingkat kesuksesan kegiatan budidaya, maka keberadaan biota yang dapat dijadikan induk berproduktivitas tinggi juga merupakan salah satu parameter penting. Hal ini dikarenakan keberhasilan dari kegiatan budidaya perikanan ditunjang oleh suplai benih ikan maupun udang yang diharapkan dihasilkan oleh induk unggul relative cukup. Benih ikan atau udang selain berasal dari alam juga diusahakan melalui hasil hatchery. Pada saat ini ketersediaan benih dari kegiatan hatchery lebih diusahakan dari pada bergantung pada alam, karena dalam kegiatan bisnis ketersediaan benih secara kontinyu dari kegiatan hatcery lebih memperkecil resiko kerugian berusaha. Tetapi induk yang di introduksikan dari alam tetap merupakan komoditas yang memiliki keunggulan-keunggulan lebih dari pada induk yang diusahakan dari balai benih.

Pengambilan induk langsung dari alam merupakan alternatif yang sangat efektif bagi penyediaan induk dalam kegiatan budidaya udang serta memiliki keunggulan-keunggulan antara lain adalah dapat diperoleh dalam keadaan matang kelamin, kualitasnya baik serta dapat lebih mudah dikembangkan lagi melalui penelitian-penelitian biologi, genetika maupun rekayasa bioteknologi. Namun beberapa kekurangan induk yang diambil dari alam adalah pada saat diperoleh dalam keadaan luka yang disebabkan oleh alat tangkap, umurnya sulit diketahui dan umumnya berjenis kelamin betina.

Propinsi Aceh memiliki panjang garis pantai $\pm 1.600 \mathrm{~km}$ dengan luas territorial $\pm 1.600 \mathrm{~km}^{2}$, dan perairan Zona Ekonomi Ekslusif (ZEE) seluas $\pm 534.520 \mathrm{~km}^{2}$ yang diantaranya terdapat 11 kabupaten dan 4 kota pesisir. Wilayah perairan tersebut sangat potensial serta mengandung keanekaragaman hayati tinggi terutama sumberdaya hayati dari jenis crustacea. Daerah-daerah yang diduga mengandung stok induk udang berkualitas tinggi adalah perairan wilayah Kabupaten Aceh Jaya.

Proses penetapan titik ordinat induk udang di ketiga perairan kabupaten tersebut merupakan langkah awal yang dapat dilakukan guna menginventarisasi kawasan-kawasan habitat induk udang yang potensial. Data dan informasi awal ini dapat digunakan bagi aktivitas pembudidayaan udang di wilayah Aceh, maupun daerah lainnya karena tingkat ketersediaan induk merupakan hal yang menentukan tingkat keberhasilan dalam suatu kegiatan budidaya.

Untuk menentukan titik ordinat bagi induk udang di wilayah perairan Kabupaten Aceh Jaya, Aceh Utara dan Aceh Timur, data dan informasi yang perlu disajikan antara lain adalah titik ordinat yang diduga memiliki potensi induk udang, pemetaan titik ordinat induk udang, kualitas habitat, parameter kualitas perairan yang berguna untuk mendapatkan kondisi actual periaran, kondisi sosial-ekonomi-budaya masyarakat, pola proyeksi penggunaan serta berbagai bentuk ancaman terhadap sumberdaya sehingga akan diperoleh karakteristik kawasan induk udang tersebut. Titik ordinat, Karakteristik kawasan nantinya akan dianalisis serta digabungkan dengan data GIS dalam pembuatan peta areal sumber induk udang.

Aplikasi teknologi Sistem Informasi Geografis (SIG) merupakan alternatif yang dapat membantu mengidentifikasi titik ordinat lokasi atau kawasan yang potensial untuk dilakukan penangkapan induk udang unggul bagi kegiatan budidaya udang terutama dalam proses pembenihan. Hal tersebut dimungkinkan karena teknologi berbasis komputer tersebut mampu menampung, menyimpan, mengolah dan memanipulasi data yang bereferensi spasial sehingga menghasilkan keluaran sesuai dengan tujuan yang diinginkan. Keluaran dari proses aplikasi SIG tersebut dapat dijadikan sebagai dasar pertimbangan perencanaan daerah penangkapan induk udang potensial bagi kegiatan pembenihan udang bagi balai benih.

\section{Bahan dan Metode}

\subsection{Waktu dan tempat}

Ruang lingkup lokasi penelitian adalah daerah penyebaran induk udang di perairan Kabupaten Aceh Jaya (Gambar 1).

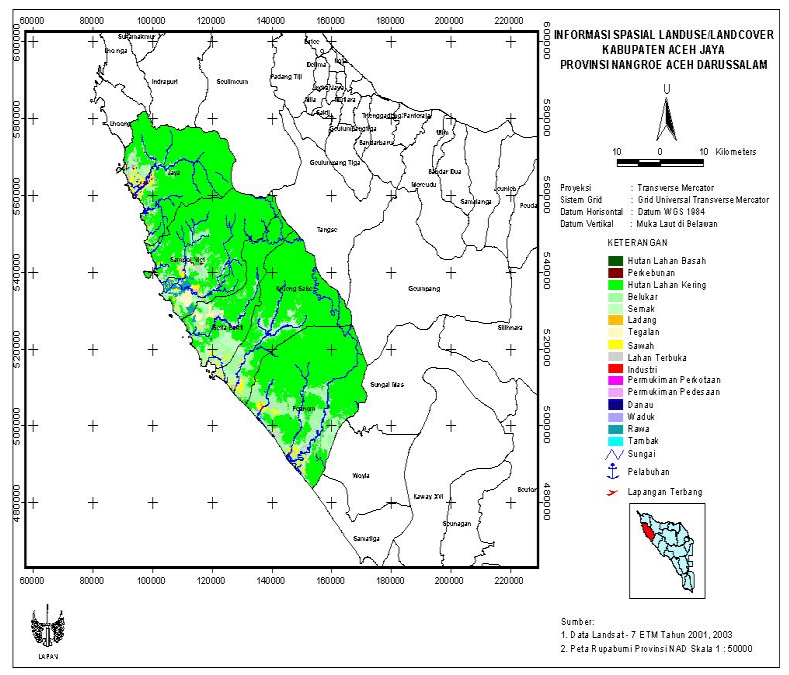

Gambar 1. Lokasi penelitian

Survei lapangan dilaksanakan selama satu bulan yang selanjutnya dilakukan pengolahan data lapangan yang terdiri dari data primer maupun data sekunder yang telah berhasil dikumpulkan. Data primer diperoleh dari lapangan melalui pengukuran kualitas perairan, wawancara dengan nelayan penangkap maupun konsumen komoditas udang windu di daerah penangkapan udang windu. Sedangkan data sekunder di peroleh dari dinas maupun instansi terkait yang berhubungan kegiatan kelautan dan perikanan seperti Dinas Kelautan dan Perikanan setempat maupun instansi pemerintahan lainnya.

\subsection{Bahan dan alat}

Dalam pelaksanaan penelitian dilapangan, bahan-bahan yang digunakan antara lain adalah: (1) citra satelit Landsat ETM, peta rupa bumi, peta topografi, peta kontur arus dan salinitas, peta lingkungan laut, dan peta lainnya, (2) data oceanografi antara lain, salinitas, temperatur, kekeruhan, $\mathrm{pH}$, kecepatan arus, kedalaman, dan lain-lain, (3) data Biologi meliputi terumbu karang, mangrove, ikan karang, lamun, dan organisme lainnya. Sedangkan peralatan yang digunakan dalam kegiatan ini meliputi: (1) kamera untuk perekaman daerah sebaran induk udang, (2) hand refraktometer, digunakan untuk mengukur salinitas, (3) Thermometer, digunakan untuk mengukur suhu perairan, (4) $\mathrm{pH}$ indicator, digunakan untuk mengukur $\mathrm{pH}$ perairan, (5) global positioning system, digunakan untuk 
menentukan lokasi dan (6) curent drag, digunakan untuk mengestimasi kecepatan arus.

\subsection{Pembentukan basis data}

\subsubsection{Pengumpulan Data}

Data yang dikumpulkan terdiri atas data spasial dan nonspasial/atribute yang dapat diperoleh dari empat sumber, yaitu: data lapangan seperti hasil survei, wawancara dan eksplorasi, data sekunder dari catatan statistik, laporan atau sumber lainnya, peta-peta baik digital maupun analog, dan data penginderaan jauh. Kesemua data yang diperoleh terlebih dahulu diinventarisasi guna memberikan kemudahan bagi peneliti untuk memahami struktur data yang telah dikumpulkan.

\subsubsection{Pemasukan dan pengolahan data}

Secara umum pemasukkan data ke dalam basis data dapat dilakukan dengan beberapa cara yaitu:

\section{a. Memasukan data kedalam bentuk wroksheet}

Proses pemasukkan data dalam bentuk worksheet dapat dilakukan dengan mengunakan software Microsoft excell. Datadata tersebut disusun sesuai kaidah penyusunan data base karena untuk selanjutnya dipakai dalam berbagai analisis. Pada analisis menggunakan Sistem Informasi Geografi (SIG) data tersebut harus memiliki referensi geografi bisa berdasarkan koordinat bumi atau bisa juga memakai referensi batas administrasi desa pesisir.

\section{b. Digitasi peta analog}

Proses digitasi yang digunakan adalah digitasi screen to screen. Proses awal dari digitasi screen to screen adalah data/peta yang hendak didigitasi terlebih dahulu di scane. Selanjutnya dilakukan koreksi geografis dan setelah itu proses digitasi dimulai. Maksud dari pemasukkan data dengan cara digitasi screen to screen adalah mengubah format data dari yang bersifat analog menjadi digital sehingga data tersebut dapat dipakai dalam analisis SIG selanjutnya. Data yang dihasilkan dari proses ini terdiri dari dua bentuk yaitu data spasial dan atribute.

\section{c. Image processing}

Image processing merupakan salah satu tahapan utama dalam pembentukan informasi untuk berbagai keperluan. Image Processing adalah tehnik pengolahan data dengan cara mengekstrak informasi yang terkandung dari hasil rekaman citra satelit, peta-peta analog dan foto udara.

\subsubsection{Import data dari sumber lain}

Pada proses ini, data-data yang telah ada dalam berbagai bentuk format data diseragamkan kedalam satu format data yaitu format data .shp. Data hasil olahan citra satelit yang berbentuk raster diubah menjadi data dalam format vektor dan selanjutnya dibawa ke lingkungan Arc View. Begitu juga format data-data spatial dan atribute lainnya yang berasal dari berbagai macam bentuk format data diseragamkan kedalam format .shp.

\subsubsection{Analisis data}

Analisis yang terdapat pada Sistem Informasi Geografi (SIG) yang digunakan dalam penelitian secara garis besar dapat kategorikan kedalam 3 kelompok, diantaranya: analisis proximity yaitu pembuatan buffer dalam artian membuat suatu coverage baru berupa zona penyangga disekeliling feature dari coverage input (titik, garis, dan poligon), analisis spasial/overlay yaitu proses penampakkan/tumpang tindih coverage, dilakukan untuk menganalisis dan mengidentifikasi hubungan spasial (keruangan dan informasinya) antara feature-feature dari coverage, dan analisis site suitability sering disebut analisis SQL digunakan untuk eksplorasi terhadap basis data dari hasil analisis overlay, dimana dalam analisis ini digunakan untuk mencari wilayah yang diinginkan berdasarkan kriteria yang telah ditetapkan atau disetujui ( ESRI, 1990; Bonham-Carter, 1994).

Analisis keruangan adalah analisis berdasarkan keruangan yang meliputi posisi suatu wilayah terhadap wilayah lainnya, jenis lahan yang ada dalam suatu wilayah tertentu dan fungsi ekologis wilayah tersebut. Analisis spasial/keruangan dibagi atas dua tahap, tahap awal yaitu penyusunan matriks kesesuaian yang dilanjutkan dengan kegiatan overlay. Matriks kesesuaian digunakan untuk menduga berbagai aktivitas penangkapan di Ketiga kabupaten tersebut. Matriks kesesuaian dibuat melalui studi pustaka dan hasil penelitian. Pada kegiatan overlay, metode yang digunakan adalah model union dimana hasil akhirnya membentuk basis data secara keseluruhan dari coverage yang ditumpang tindihkan (Mauble et al., 1993). Adapun ilustrasi dari metode overlay yang digunakan dapat dilihat pada Gambar 2.

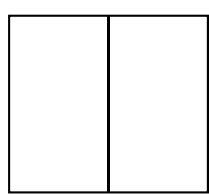

Coverage

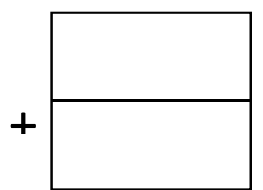

Coverage

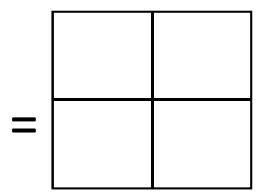

Coverage Baru
Gambar 2. Ilustrasi proses overlay model union

Setelah proses overlay, langkah selanjutnya menghitung nilai indeks overlay berdasarkan metode Indeks Overlay Model (Bonham - Carter dalam Awal, 1998) dengan model matematisnya adalah sebagai berikut:

$$
S=\left(\frac{\sum S_{i j} * W_{i}}{\sum W_{i}}\right)
$$

Dimana:

$$
\begin{aligned}
& \mathrm{S}=\text { Indeks terbobot poligon terpilih } \\
& \mathrm{S}_{\mathrm{ij}} \quad=\text { Nilai kelas ke }-\mathrm{j} \text { dalam peta } \mathrm{ke}-\mathrm{i} \\
& \mathrm{W}_{\mathrm{i}} \quad=\text { Bobot peta ke }-\mathrm{i}
\end{aligned}
$$

Nilai indeks overlay mengambarkan tingkat kesesuaian yang terbentuk. Nilai indeks overlay yang terbentuk berkisar dari 3 sampai 1. Dimana jika bernilai 3 maka lokasi tersebut memiliki kriteria kesesuaian yang tinggi. 


\section{Hasil dan pembahasan}

Kabupaten Aceh Jaya merupakan kabupaten pesisir barat yang memiliki tingkat produktivitas perairan serta tingkat biodeversity yang sangat tinggi. Hal ini dimungkinkan oleh letak perairan, kondisi lingkungan daratan dan kondisi perairan sangat sesuai untuk mendukung sistem kehidupan organisme perairan. Salah satu organisme perairan yang memiliki biodeversity tinggi di perairan Kabupaten Aceh Jaya adalah jenis Crustacea. Beberapa jenis Crustacea seperti udang telah ditemukan didaerah ini dalam beberapa spesies seperti udang windu, lobster, udang jerbung dan sebagainya. Aktivitas penangkapan beberapa jenis udang juga telah dilakukan di perairan Aceh Jaya dengan menggunakan berbagai macam alat tangkap dan sarana penangkapan yang cukup beragam. Jenis udang yang ditangkap dipergunakan untuk berbagai tujuan seperti udang konsumsi serta untuk kegiatan budidaya seperti penyediaan induk udang alam.

\subsection{Titik ordinat sebaran induk udang}

Penentuan titik ordinat induk udang merupakan salah satu langkah bagi pemenuhan kebutuhan akan induk yang berasal dari alam melalui teknik penangkapan yang diharapkan ramah lingkungan serta melalui teknis tangkap yang menghasilkan udang tetap dalam kondisi yang hidup serta berkualitas. Cara dan teknis penangkapan ini, walaupun secara tradisional telah mulai diterapkan oleh beberapa nelayan penangkap di beberapa kabupaten di Provinsi Nanggroe Aceh Darussalam seperti yang telah diterapkan oleh nelayan penangkap induk udang di Kabupaten Aceh Jaya. Sistem dan cara penangkapan yang sederhan efektif tersebut hingga sekarang masih dilakukan walaupun dengan metode-metode yang relatif masih sangat sedehana.

Kabupaten Aceh Jaya yang merupakan kabupaten pemekaran pecahan dari Kabupaten Aceh Barat adalah salah satu sentra produksi udang windu yang berkualitas tinggi. Hal ini sangat didukung oleh kondisi lingkungan perairan serta ekosistem pendukung kehidupan organisme tersebut. Kondisi sosial budaya masyarakat nelayan di kabupaten ini juga sangat menentukan produksi udang terutama induk udang. Produksi udang khususnya induk udang di daerah tersebut semakin bertambah seiring dengan semakin bertambahnya jenis dan kuantitas alat penangkapan serta sumberdaya manusia pelaku usaha perikanan tersebut.

Berdasarkan hasil survey, nelayan penangkapan induk udang di Kabupaten Aceh Jaya biasanya melakukan penangkapan induk udang dengan metode konvensional dan menggunakan alat tangkap jaring udang atau trammel net. Aktivitas penangkapan induk udang biasanya merupakan aktivitas yang dilakukan secara bersamaan dengan aktivitas penangkapan ikan. Daerah tangkapan induk udang pada umumnya masih dikategorikan dalam perairan pantai atau perairan teluk yang diidentifikasikan sebagai daerah habitat udang. Jenis-jenis udang maupun induk udang yang ditangkap oleh nelayan pada umumnya adalah udang windu dengan berbagai jenis kelamin serta ukuran yang beragam.

Titik-titik ordinat penangkapan induk udang di Kabupaten Aceh Jaya berpusat di daerah teluk yang dikenal oleh nelayan dengan teluk calang. Daerah penangkapan ini memiliki titik-titik sebaran yang hampir berdekatan antara satu titik dengan titik lainnya (Gambar 3).
PETA SEBARAN TITIK PENANGKAPAN UDANG WINDU DI KABUPATEN ACEH JAYA

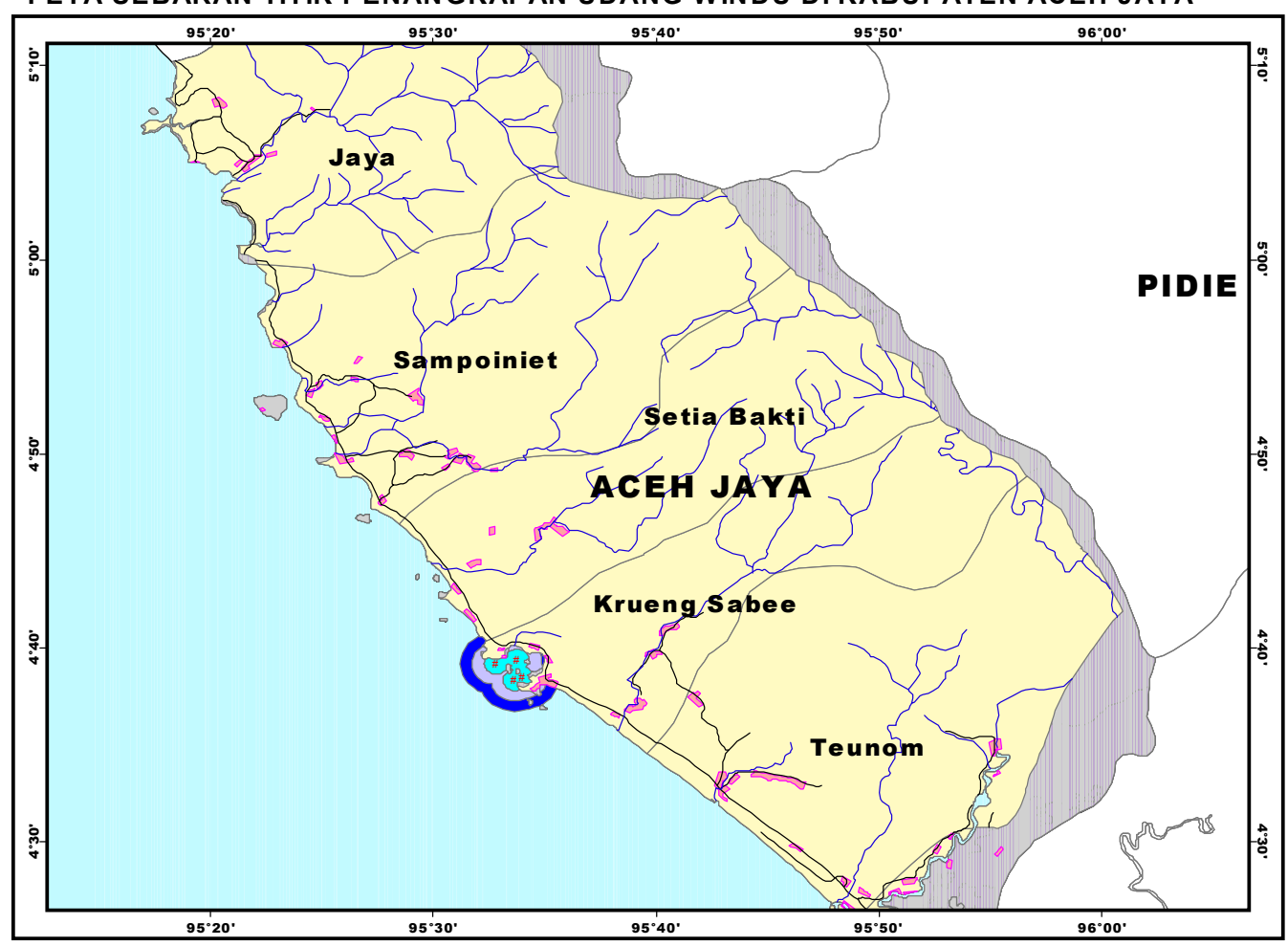

Gambar 3. Titik ordinat penangkapan induk udang windu di perairan Kabupaten Aceh Jaya 
Jumlah titik ordinat penangkapan di teluk Calang tersebut berjumlah 4 titik dengan kondisi perairan dan ekosistem yang hampir seragam antara satu titik ordinat dengan titik ordinat lainnya. Adapun titik-titik ordinat tersebut berada pada:

1. H $95^{\circ} 34^{\prime}$ bujur timur dan $04^{\circ} 38^{\prime}$ lintang utara

2. H $95^{\circ} 33^{\prime}$ bujur timur dan $04^{\circ} 39^{\prime}$ lintang utara

3. H $95^{\circ} 34^{\prime}$ bujur timur dan $04^{\circ} 40^{\prime}$ lintang utara

4. $\mathrm{H} 95^{\circ} 34^{\prime}$ bujur timur dan $04^{\circ} 33^{\prime}$ lintang utara

Tersebarnya titik ordinat penangkapan induk udang yang hanya di sekitar wilayah teluk hampir berdekatan serta tingkat produksi yang masih cukup rendah lebih disebabkan oleh beberapa faktor antara lain: (1) kondisi perairan di daerah penangkapan sangat sesuai dengan kondisi perairan habitat induk udang dalam melangsungkan siklus kehidupananya, (2) terbatasnya sarana dan prasarana penangkapan yang memungkin nelayan dapat menangkapn lebih jauh dari daerah pantai, (3) terbatasnya cara dan teknologi penangkapan yang di kuasai oleh para nelayan penangkapan induk udang, (4) teknologi dan penanganan pasca penangkapan yang kurang di kuasai dengan baik akan sangat mempengaruhi lama dan jarak penangkapan, dan (5) pada umumnya nelayan malakukan penangkapan induk udang hanya merupakan aktivitas sambilan pada saat nalayan melakukan penangkapan ikan.

Daerah penangkapan yang sempit diduga juga memberikan indikasi terhadap hasil produksi induk udang. Kondisi ini dapat diperbaiki dengan mencari daerah tangkapan baru. Dari hasil survey menunjukkan bahwa kondisi perairan yang masih sangat bagus memungkinkan nelayan melakukan perluasan daerah penangkapan hingga radius 2 kilometer dari titik penangkapan awal. Pendugaan ini di hasilkan dari. Hal ini dimungkinkan karena kondisi biofisik perairan yang hampir sama dengan titik awal penangkapan.

\subsection{Daerah sentra penangkapan udang windu}

Daerah penangkapan induk udang di Kabupaten Aceh Jaya tersentral di Kecamamatan Krueng Sabee dengan sebaran di beberapa desa seperti Desa Sentosa, Desa Batee Tutong, Desa Bahagia, dan Desa Krueng Sabee (Gambar 4).
Seluruh desa tersebut merupakan desa pesisir yang memiliki nelayan dalam jumlah yang cukup besar. Nelayan di Kecamatan Krueang Sabee dapat di ketegorikan sebagai nelayan tradisional dengan mengaplikasikan sistem penangkapan yang masih cukup sederhana. Sarana penangkapan yang digunakan pada umumnya berupa perahu tempel dengan alat tangkap berupa jaring udang atau trammel net. Aktivitas penangkapan oleh nelayan di beberapa desa tersebut dilakukan di daerah teluk Calang dengan lokasi pada daerah yang memiliki tutupan terumbu karang yang masih cukup baik dan berada di sekitar pulau-pulau kecil di teluk. Aktivitas penangkapan induk udang di Kabupaten Aceh Jaya telah dimulai dari tahun 1990 hingga sekarang, dengan waktu penangkapan pada pagi dan malam hari dengan kedalaman perairan berkisar 20-10 meter. Hasil tangkapan induk udang di tiap daerah sentra produksi sangat bervariasi dari 5-10 kg perhari.

\subsection{Parameter kualitas air}

Parameter-parameter perairan yang telah diukur menunjukkan seluruh titik-titik ordinat tersebut memiliki kondisi yang sangat sesuai bagi sistem kehidupan udang. Parameter kualitas air seperti suhu, salinitas, DO, pH dan kecepatan arus akan sangat mempengaruhi kualitas hidup udang. Udang sangat menginginkan kondisi perairan yang spesifik bagi hidupnya. Apabila terjadi salah satu perubahan yang signifikan dari parameter perairan akhirnya akan dapat juga mempengaruhi sistem dan siklus kehidupannya. Dari beberapa parameter perairan yang di ukur diperoleh kualitas perairan seperti tersaji Tabel 1.

Kondisi biofisik ekosistem pendukung kehidupan udang seperti ekosistem terumbu karang di perairan tempat titik ordinat penangkapan induk udang maupun perairan yang di duga memiliki peluang dijadikan daerah penangkapan masih tergolong baik. Tingkat ketersediaan tutupan ekosistem mangrove yang juga merupakan ekosistem pendukung, memiliki hubungan positif dengan tingkat ketersediaan induk udang. Daerah tangkapan baru bisanya akan dapat di temukan pada daerah yang berdekatan dengan ekosistem ini. Kedua ekosistem ini di wilayah pesisir Kabupaten Aceh Jaya terutama Kecamatan Krueng Sabee yang merupakan sentra produksi udang windu masih dikategorikan baik.
PETA KARAKTERISTIK KEGIATAN
PENANGKAPAN UDANG WINDU DIKABUPATEN ACEH JAYA

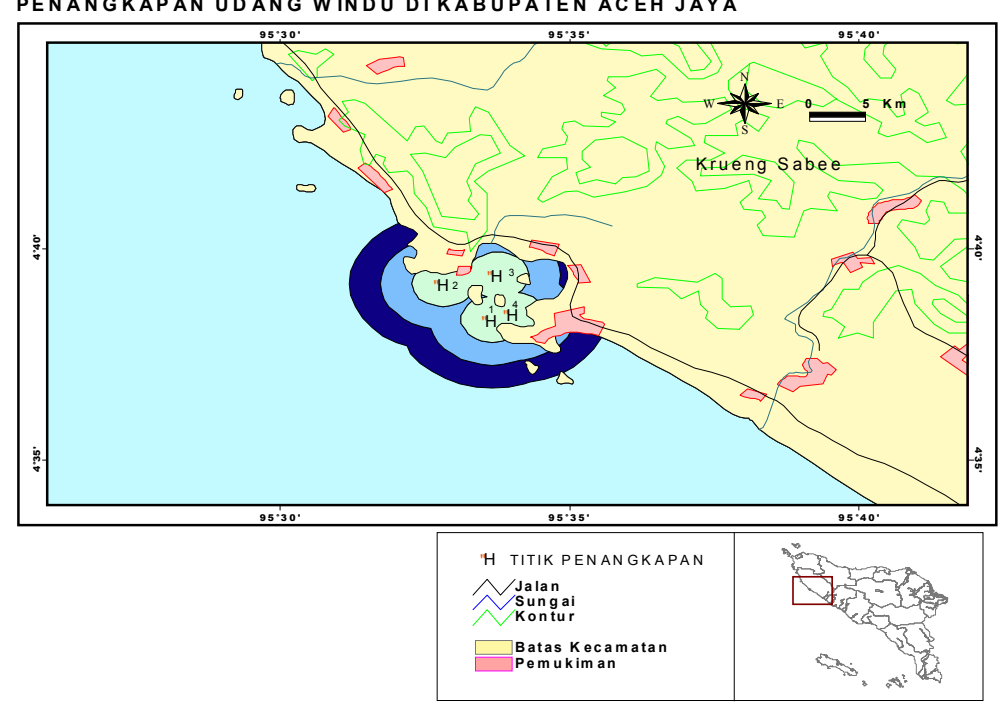

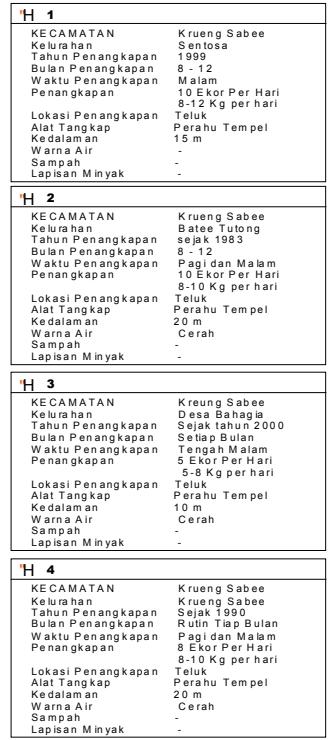

Gambar 4. Sentra penghasil induk udang windu 
Tabel 1.

Parameter kualitas perairan di beberapa titik ordinat induk udang

\begin{tabular}{|c|c|c|c|c|c|c|c|}
\hline \multirow{2}{*}{ No } & \multirow{2}{*}{ Titik ordinat } & \multicolumn{6}{|c|}{ Parameter kualitas perairan } \\
\hline & & Suhu $\left({ }^{\circ} \mathrm{C}\right)$ & Salinitas (\%o) & Kecepatan arus $(\mathrm{m} / \mathrm{s})$ & $\mathrm{DO}(\mathrm{ppm})$ & $\mathrm{pH}$ & Warna Air \\
\hline $\mathrm{H} 1$ & $95^{0} 34^{\prime} \mathrm{BT}-04^{0} 38^{\prime} \mathrm{LU}$ & 28 & 31 & 0,2 & $6 \mathrm{ppm}$ & 7,5 & Cerah \\
\hline $\mathrm{H} 2$ & $95^{\circ} 33^{\prime} \mathrm{BT}-04^{\circ} 39^{\prime} \mathrm{LU}$ & 28 & 31 & 0,2 & $6 \mathrm{ppm}$ & 7,5 & Cerah \\
\hline H3 & $95^{\circ} 34^{\prime} \mathrm{BT}-04^{\circ} 40^{\prime} \mathrm{LU}$ & 29 & 30 & 0,2 & $6 \mathrm{ppm}$ & 7 & Cerah \\
\hline $\mathrm{H} 4$ & $95^{\circ} 34^{\prime} \mathrm{BT}-04^{\circ} 33^{\prime} \mathrm{LU}$ & 29 & 30 & 0,3 & $6 \mathrm{ppm}$ & 7,5 & Cerah \\
\hline
\end{tabular}

\section{Bibliografi}

Adnyana, I.M.K., 1992. Studi Tentang Stok Udang Jerbung di Laut Arafura dan Sekitarnya. Skripsi (tidak dipublikasikan). Program Studi Ilmu Kelautan, Fakultas Perikanan Institut Pertanian Bogor, Bogor. 97 hal.

Bonham-Carter, G.F., 1994. Geographic Information System for Geoscientists: Modelling with GIS. Ottawa, Canada.

Dahuri, R., J. Rais, S.P. Ginting, M.J. Sitepu, 2001. Pengelolaan Sumber daya Wilayah Pesisir dan Lautan Secara Terpadu. PT Pradnya Paramita. Jakarta, Indonesia. 328 hal.

ESRI, 1990. Understanding GIS: The Arc/Info Method Environment al System Research Institute. Redlands, CA. USA.

Mauble, D., D.J. Peuquet, 1993. Geographic Information System and Remote Sensing. Manual of Remote Sensing. American Society of Photogrammetry. All Church. Virginia. USA. 